Ciel variable

CIEL VARIABLE

Art, photo, médias, culture

\title{
The World as Will and Representation
}

Numéro 71, mars 2006

Un monde d'images

Image World

URI : https://id.erudit.org/iderudit/20604ac

Aller au sommaire du numéro

Éditeur(s)

Les Productions Ciel variable

ISSN

1711-7682 (imprimé)

1923-8932 (numérique)

Découvrir la revue

Citer cet article

(2006). The World as Will and Representation. Ciel variable, (71), 24-27.

Ce document est protégé par la loi sur le droit d'auteur. L'utilisation des services d'Érudit (y compris la reproduction) est assujettie à sa politique d'utilisation que vous pouvez consulter en ligne.

https://apropos.erudit.org/fr/usagers/politique-dutilisation/
Cet article est diffusé et préservé par Érudit.

Érudit est un consortium interuniversitaire sans but lucratif composé de l’Université de Montréal, l'Université Laval et l'Université du Québec à

Montréal. Il a pour mission la promotion et la valorisation de la recherche.

https://www.erudit.org/fr/ 


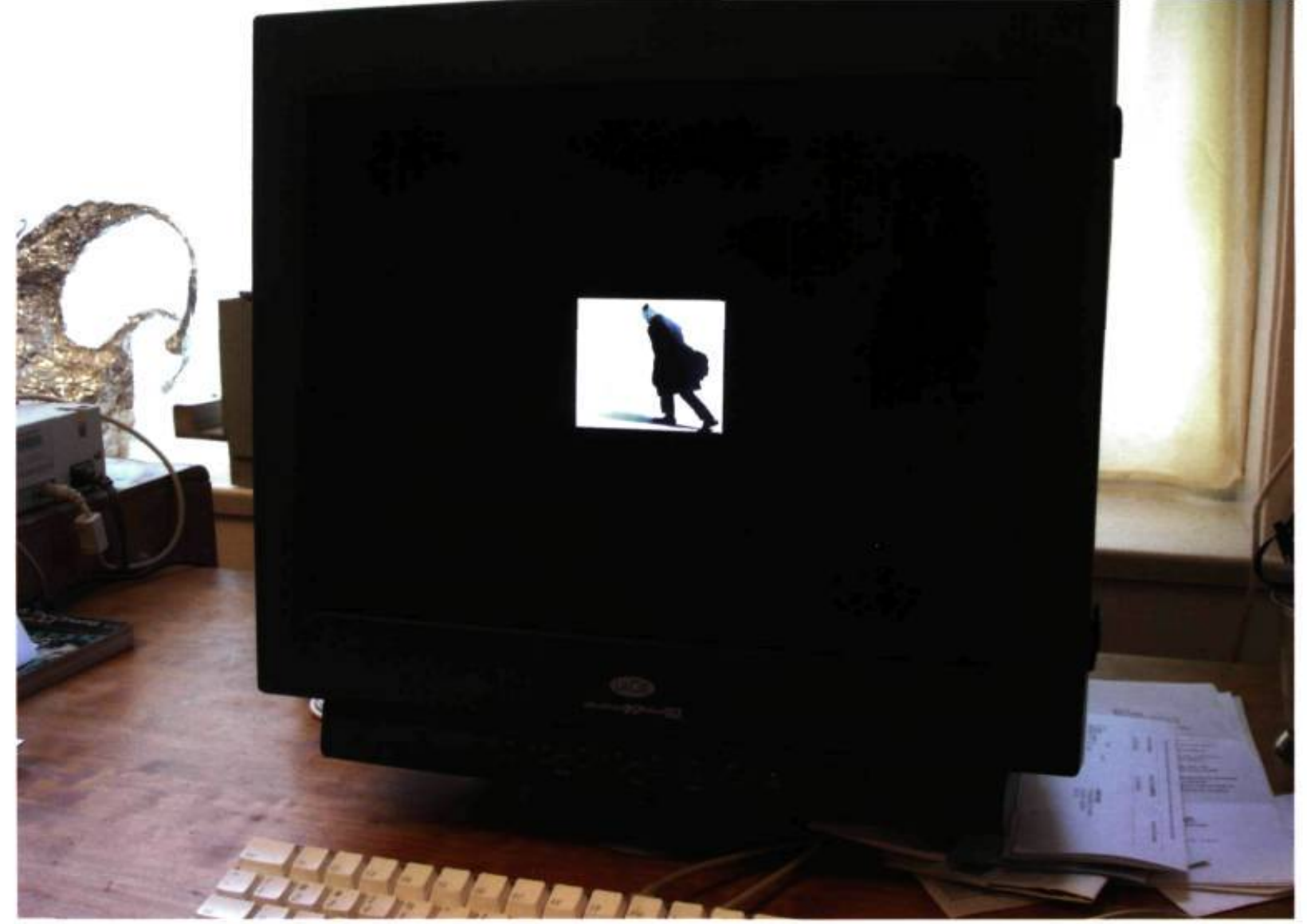

\section{Notes on The World as Will and Representation (Archive, 2004-) ROYARDEN}

I have collected images since I was a child; the first were usually cut with scissors from Life magazine. I also then began collecting images in my mind. I remember the journalistic images of the civil-rights marches, of Vietnam, the Beatles, and so on, that began to accumulate in my mental archive. In the sixties, life was still quiet enough for a child to find the necessary boredom, the empty time, to be prompted to browse through the Encyclopaedias Britannica. I was fascinated by all of the different subjects and how they were ordered, but I was always drawn more to the pictures than to the texts. Although I couldn't understand what was written about, say, "astrophysics," I learned the language of the images produced by that discipline. I noticed that each subject seemed to have a different style of picture.

Later, when I became interested in visual art as such, I recognized that many artists worked with encyclopedic or archival models. Instead of trying to make new images, they took images from the world as a raw material. There is a tradition that runs from the collages of Kurt Schwitters to Rauschenberg, Andy Warhol, Sigmar Polke, Gerhard Richter, Hans-Peter Feldmann, Vija Celmins, Richard Prince, Sherrie Levine, and Cady Noland. This tradition has often been characterized as a counter-tradition that aims to destroy a traditional idea of art based on originality. While I certainly reject that avant-gardiste claim as sophomoric and tiresome, it is clear that this new tradition - of artists using received images - has expanded the vocabulary and territory of art. For my own practice, Hans-Peter Feldmann is the most important artist in this line - for being the first to step over into pure, unqualified appropriation.

I have always kept files of paper cuttings; in 1991, I started to keep a folder called The World as Will and Representation. This title itself is borrowed from the major work by the philosopher Arthur Schopenhauer. My intention was eventually to make collages from these cuttings, but I wanted to wait until I had a critical mass of images to work from. I collected paper images until I discovered the Internet and image search engines. Suddenly, a quantity of images was available that seemed infinite. After a few years of collecting online, it became apparent that the supply was not infinite after all; I started to get a sense of the shape and limits of the online image archive.

As I collected images, I ordered them in titled folders that were alphabetically ordered by default. My criteria for the images were that they be photographic and that they clearly show something that existed in the world. The chosen images also had to be vernacular, or "non-art." I wanted subject-oriented, rather than author-oriented, imagery. These criteria are increasingly violated - like every system, mine is open to corruption. When image searching, I randomly follow my interests. For days, I might search for images of "rubber" and then move on to "anechoic chambers" or "Charlotte Rampling." It is almost idiotic work that can be done half-asleep, but I suppose I have a deep interest in the nature and scope of the image world. My façade of encyclopedic objectivity is always slipping, and that is where the poetry and fun enter the project. If my archive is about the necessity of collecting and ordering images of the world, it is also about the sheer folly of such an enterprise.

By 2004 , I had still not begun to make collages from my archive, and I then realized that it might be interesting to return these images to their source, the Internet. A QuickTime movie was made that is a simple slide show of the ten thousand images in the archive. It was important that the images appear completely surrounded by black - that the project completely take over the computer screen. A sound loop was fashioned from part of the intro to Timmy Thomas's 1973 hit "Why Can't We Live Together?" I wanted something with a metronome-like, mechanical simplicity. Thomas's tune also offered soul and anticipation, not to mention the suggestion of a universal will. I like to think that Schopenhauer would approve of the song. The archive continues to grow and I plan to update the Web project to twenty thousand images soon. I am not a technically minded person, and this project has taught me that the Internet is a very unstable medium. Applications are constantly being updated and changed, and no matter how one designs a site, it will look and behave differently on different people's computers - universality thwarted again. 
